\title{
Hydraulic Studies for Proposed Oddaimavadi Bridge at Valachchena
}

\section{G. T. Dharmasena}

Abstract: The impact of any major restriction on a river has to be considered in the design of bridges due to rapid urbanization of river estuaries. This aspect can not be ignored any longer and therefore it is necessary to verify the hydraulic conditions before and after a new construction. The existing bridge at Oddaimavadi over the Maduru Oya in Batticaloa District needs replacement. Major land use changes had taken place, since the construction of the existing bridge. The specific objective of this study was to determine the minimum span of the bridge to avoid any significant inundation in the upstream and further to keep the deck level of the bridge above a safe level to withstand a major flood of rare probability.

A numerical hydraulic model was set up for the river estuary to simulate the conditions during a design flood of 100 year return period. By simulation the deck level of the bridge was kept sufficiently above the high flood level and the span of the bridge was optimized to minimize the upstream flooding. The HEC-RAS hydraulic model for hydraulic modeling and HEC-HMS model for hydrological modeling developed by the US Army Corps of Engineers were used in this study for simulation

\subsection{Introduction}

The proposed Oddaimavadi Bridge at Valachchena will be constructed on the Habarana - Polonnaruwa- Batticaloa road by the side of the existing bridge. The existing bridge is $248 \mathrm{~m}$ long with 5 spans which serves both highway traffic and railway providing access over the Maduru Oya to either side. This bridge was constructed in 1922 during the British rule, when the Maduru Oya basin was less developed. The proposed bridge will be constructed parallel to the existing bridge and serve for highway traffic, while the existing bridge will be reserved only for railway traffic. The new bridge is located $4.5 \mathrm{kms}$ upstream of the river mouth.

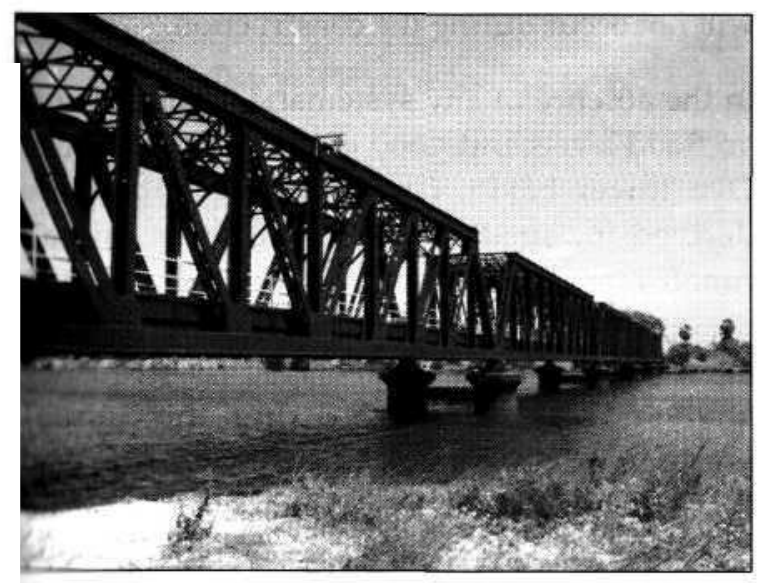

figure 1: Existing Bridge at Oddaimavadi
The Maduru Oya originates from Mahiyangana in the Badulla district and has a drainage area of 1541.0 sq.kms with a mild slope during the last $50 \mathrm{kms}$. Since then this river basin was not populated during the construction of the existing bridge and remained less developed until the restoration of the Vakaneri tank and the Maduru Oya reservoir.

The Punani anicut across the Maduru Oya is located, $34.0 \mathrm{kms}$ upstream of the river mouth and has a length of $50 \mathrm{~m}$ with 10 radial gates. It intercepts 1473 sq.kms of the drainage area. The Maduru Oya reservoir located in the head catchment has a capacity of $598 \mathrm{mcm}$ and intercepts 448.0 sq.kms of the catchment. Fig. 1 shows the existing bridge and Fig.2 shows the schematic diagram of the Maduru Oya river basin with other relevant features.

Normally bridges are constrictions to the flow of water and exert friction from abutments and piers. This will tend to raise the water levels upstream of rivers during major floods and can cause upstream flooding. Major land use changes had taken place in Maduru Oya since the construction of the existing bridge and

Eng. G.T.Dharmasena B.Sc.Eng, Dip. Hydrol Delf.,MIE SL, C.Eng. Graduated from the University of Ceylon in 1967 and obtained his post graduate Diplomafrom the IHE, Delft, The Netherlandsin 1979. He was the Director General of theIrrigation Department and presently Senior Hydrologist of the United Nation Office for Project Services (UNOPS) in Sri Lanka 
therefore it is necessary to verify whether the hydraulic conditions of the river estuary would change after the construction of the proposed bridge.

When a bridge or a large cross drainage work is proposed across a major river, it is customary to obtain the concurrence of the Irrigation Department (ID) for such interventions to ensure the minimum impact during floods as the ID is the statutory body responsible for flood protection in general. However the Maduru Oya basin comes under the authority of the Mahaweli Authority of Sri Lanka (MASL) and therefore this hydraulic study will be the basis to obtain the concurrence of both ID and MASL. These concurrences are pre requisites to obtain the environment clearance from the Central Environment Authority (CEA).

The objective of the study is to determine the minimum span of the bridge which can be constructed without causing a significant inundation in the upstream and further to keep the deck level of the bridge above a safe level to withstand a major flood of rare probability. In addition, the possible scouring under the bridge also has to be examined due to the transport of river bed materials during major floods.

\subsection{Methodology}

The change of hydraulic properties in the river estuary such as depth of water as a result of this new bridge was studied by developing a hydrodynamic model for the river reach coupled with a hydrological model at the head catchment. To develop a hydraulic model, 34.0 $\mathrm{kms}$ reach of Maduru Oya was selected between the sea and the Punani anicut. The model was simulated without the bridge and with the bridge for the design flood of 100 year return period. By simulation the deck level of the bridge was adjusted sufficiently above the high flood level and the span of the bridge also was varied to minimize the upstream flooding. For hydrodynamic modeling the HEC-RAS hydraulic model developed by the US Army Corps of Engineers was used. [2]

This river reach receives water at the head catchment from the Maduru Oya reservoir and also the lateral flow from the intervening catchment. Therefore as an input to the hydrodynamic model, a hydrological model is also required. In this study HEC-HMS model developed by the US Army Corps of Engineers was used to develop flood hydrographs. [2]

A numerical hydraulic model requires topographical and hydrological information as model inputs. The topographical information includes river cross-sections extending to either side of the flood plain. This model will have four hydraulic boundaries. One will be at the upstream end of the reach and in this particular situation it will be the design outflow hydrograph from the Maduru Oya reservoir. Then the second boundary is the lateral flood flow generated from the local rain for the intervening catchment within the $34.0 \mathrm{~km}$ river reach. This will be neglected as the terrain is very flat and there is no considerable catchment. The third boundary is the sea level fluctuations and fluctuations during high tides and low tides. In this particular application, the sea level is assumed to vary between $0.0 \mathrm{MSL}$ and 1.0 MSL giving consideration to high and low tides during cyclonic conditions. The fourth boundary will be the inflow hydrograph from Ollimadu Aru which is a right hand tributary of Maduru Oya, just before the proposed bridge.

The scour under the bridge is due to the contraction of water under the bridge. To estimate this the Laursen's Clear water equation and Live equation were used to obtain optimistic results. For pier scouring Colorado State University (CSU) equation and for abutment scour, Hire equation was used.[2]

In order to understand the impact of coffer damming during the construction, the model was simulated for 10 year return period assuming that floods lower than that frequency will not occur during the construction.

In the absence of any systematic measurements on flood levels and flood discharges in Maduru Oya lower basin, flood hydrographs were derived for smaller catchments from rainfall runoff models for un-gauged catchments. The design rain storms are based on the rainfall intensity analysis at Valachchena. The frequency analysis was done by fitting the annual maximum daily rainfall intensities to Extreme value distribution Type I (Gumble) to estimate 1000 and 100 year storms. Then this 24 hour rainfall was distributed to shorter durations by adopting the following empirical formula.[1] 


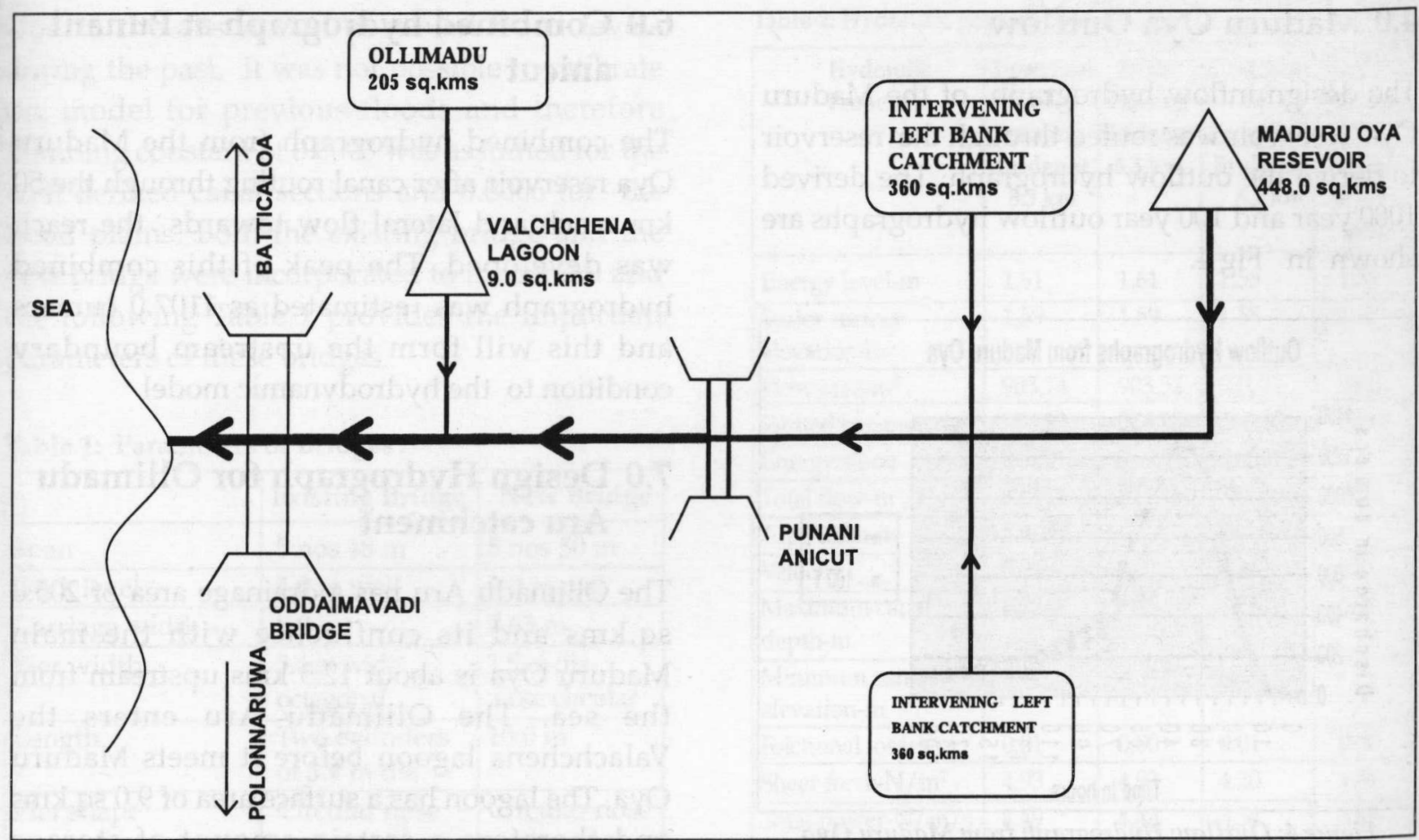

Figure 2: Schematic diagram of Maduru Oya basin

$\mathrm{It}=2.2745 * \mathrm{Rt}^{*} \mathrm{Tc}^{\wedge}-0.55$

Where,

$\mathrm{Rt}=$ Annual maximum daily rainfall for 24 hours duration in $\mathrm{mm}$ for $\mathrm{T}$ years

$\mathrm{Tc}=$ Time of concentration(minutes) or the desired duration

It = Rainfall intensity for the same $\mathrm{T}$ years $(\mathrm{mm} / \mathrm{hr})$

\subsection{Maduru Oya Flood hydrographs}

The design 1000 year inflow hydrograph for the Maduru Oya reservoir developed during the storm design stage is shown in Fig. 3 .

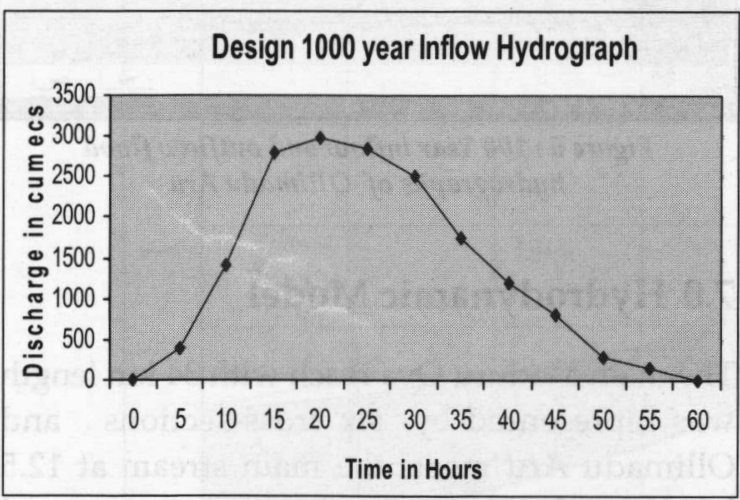

Figure 3: Design 1000 year inflow hydrograph Source: Irrigation Department/MASL
By estimating the volume and rainfall depth of this 1000 year hydrograph for Maduru Oya reservoir catchment, 100 year hydrograph was derived on the basis of the ratios of the rainfall frequencies at Valachchena. Thus the 100 year 24 hour design storm for the Maduru Oya catchment was estimated as $218 \mathrm{~mm}$. For other smaller catchments, storms were designed for short time intervals of 20 to 30 minutes.

The inflow of flood water into the river estuary takes place through the Maduru Oya reservoir and the intervening river reach below the Maduru Oya dam and the Punani anicut. The resultant hydrograph at the Punani anicut is the combination of these two flows. Then flood hydrographs were developed for the river reach below the Maduru Oya dam by the application of the HMS model for the design 100 year storm. In the HEC-HMS model the Snyder's synthetic unit hydrograph method was used. The routed hydrograph from the Maduru Oya reservoir combined with the hydrograph from the intervening catchment form the upstream boundary for the hydrodynamic model at the Punani anicut. Then a similar hydrograph was developed for Ollimadu Aru to represent 205.0 sq.kms of catchment. This hydrograph generated from Ollimadu was the input to the tributary of the hydrodynamic model. 


\subsection{Maduru Oya Outflow}

The design inflow hydrograph of the Maduru Oya reservoir was routed through the reservoir to derive the outflow hydrograph. The derived 1000 year and 100 year outflow hydrographs are shown in Fig 4.

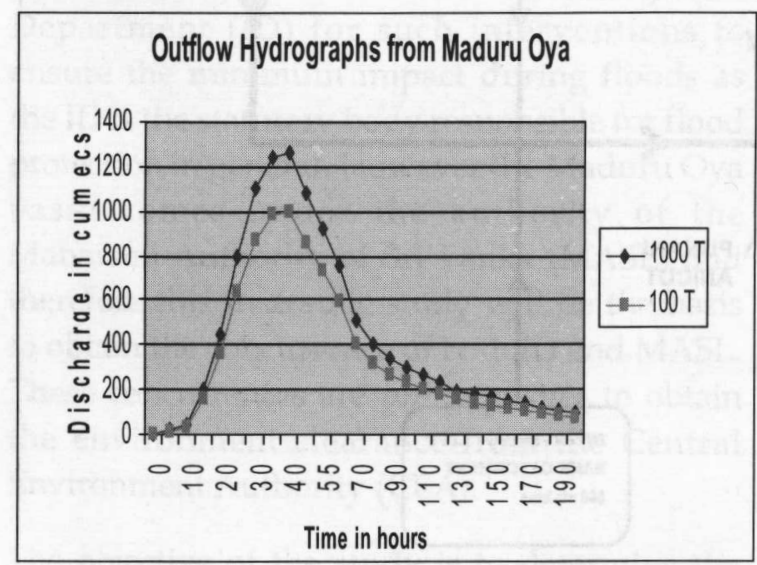

Figure 4: Outflow Hydrograph from Maduru Oya Source; Irrigation Department/MASL

\subsection{Lateral Inflow to the river reach above Punani}

The examination of the intervening catchment below the Maduru Oya dam and the Punani anicut show no major streams contributing to the lateral flow. This drainage area is very flat and has a catchment area of 700.0 sq.kms. For the development of these hydrographs, 100 year storm of 20 minute duration was adopted. Fig. 5 shows the 100 year hydrograph with a peak of 576 cumecs.

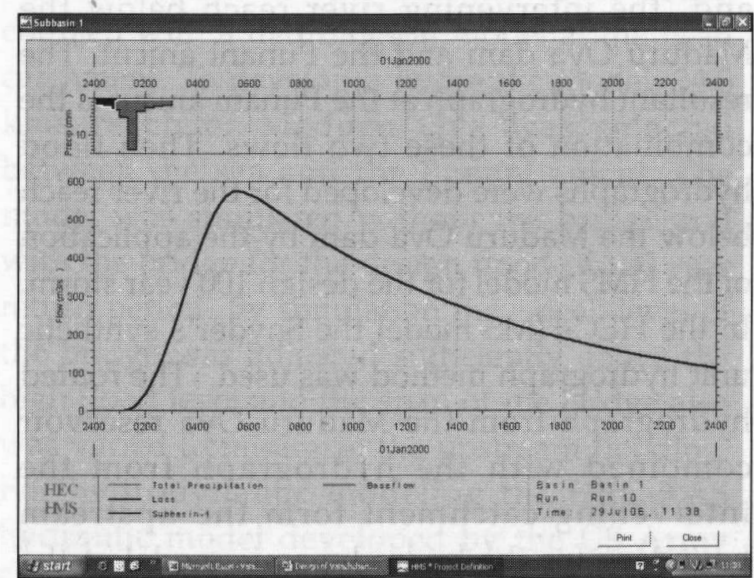

Figure 5: 100 Year hydrograph for lateral flow -240 sq.kms

\subsection{Combined hydrograph at Punani anicut}

The combined hydrograph from the Maduru Oya reservoir after canal routing through the 50 $\mathrm{km}$ reach and lateral flow towards the reach was developed. The peak of this combined hydrograph was estimated as 1107.0 cumecs and this will form the upstream boundary condition to the hydrodynamic model

\subsection{Design Hydrograph for Ollimadu Aru catchment}

The Ollimadu Aru has a drainage area of 205.0 sq. $\mathrm{kms}$ and its confluence with the main Maduru Oya is about $12.5 \mathrm{kms}$ upstream from the sea. The Ollimadu Aru enters the Valachchena lagoon before it meets Maduru Oya. The lagoon has a surface area of 9.0 sq.kms and therefore a certain amount of storage routing takes place in the lagoon Based on these parameters, 100 year inflow hydrograph was developed. The routed outflow hydrograph from the Valachchena lagoon will be the upstream boundary for the Ollimadu right hand tributary of the hydrodynamic model. The 100 year inflow and out flow hydrographs of Olimadu lagoon are shown in Fig. 6.

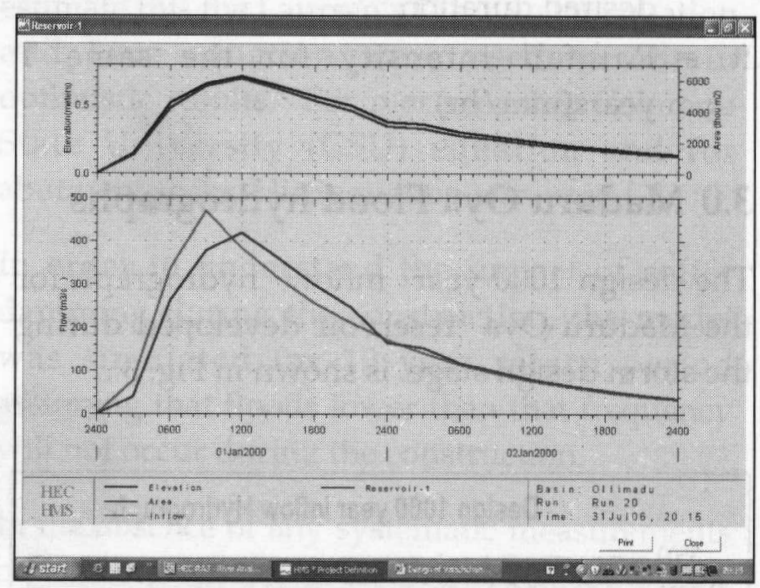

Figure 6 : 100 Year inflow and outflow flood hydrographs of Ollimadu Aru

\subsection{Hydrodynamic Model}

The main Maduru Oya reach with $34 \mathrm{~km}$ length was represented by six cross-sections and Ollimadu Aru meets the main stream at $\mathbf{1 2 . 5}$ $\mathrm{kms}$ from the sea. This tributary is represented by two cross sections. Fig 7 shows the main reach of the model. 
Due to the absence of observed flood levels during the past, it was not possible to calibrate the model for previous floods and therefore Manning constant of 0.0003 was assumed for the well defined canal sections and 0.0006 for the flood plains. Both the existing bridge and the new bridge were incorporated to the model and the following Table 1 provides the important parameters of these bridges.

Table 1: Parameters of Bridges

\begin{tabular}{|l|l|l|}
\hline & Existing Bridge & New Bridge \\
\hline Span & 5 nos $48 \mathrm{~m}$ & 5 nos $50 \mathrm{~m}$ \\
\hline Deck level & $4.0 \mathrm{~m} \mathrm{msl}$ & $6.0 \mathrm{~m} \mathrm{msl}$ \\
\hline Carriage width & $6.0 \mathrm{~m}$ & $7.63 \mathrm{~m}$ \\
\hline Pier width & $\begin{array}{l}3.4 \mathrm{~m} \text { wide } \\
\text { octagonal }\end{array}$ & $\begin{array}{l}1.5 \mathrm{~m} \text { dia- } \\
\text { nose circular }\end{array}$ \\
\hline Length & $\begin{array}{l}\text { Two cylinders } \\
\text { of } 3.4 \mathrm{~m} \text { dia. }\end{array}$ & $10.0 \mathrm{~m}$ \\
\hline Pier shape & Circular nose & Circular nose \\
\hline
\end{tabular}

\subsection{Model simulation for the design floods}

The model was simulated for a 100 year design storm by developing a 100 year hydrograph. The estimated 100 year flood hydrograph from the hydrodynamic model at the location of the new bridge shows a maximum flood lift of 1.53 $\mathrm{m}$ above the mean sea level under the new bridge. The peak discharge under the bridge during a 100 year flood is $1107.0 \mathrm{~m} 3 / \mathrm{s}$. Therefore the deck level of the bridge has to be kept at least above the $1.53 \mathrm{~m}$ msl with clearance for navigation and free board.
Table 2: Hydraulic properties of bridges

\begin{tabular}{|l|l|l|l|l|}
\hline \multicolumn{1}{|c|}{$\begin{array}{l}\text { Hydraulic } \\
\text { Properties }\end{array}$} & $\begin{array}{c}\text { Upstream } \\
\text { of } \\
\text { existing } \\
\text { Bridge at } \\
5.3 \mathrm{~km}\end{array}$ & $\begin{array}{c}\text { At the } \\
\text { existing } \\
\text { Bridge at }\end{array}$ & $\begin{array}{c}\text { Upstream } \\
\text { of } \\
\text { Proposed } \\
\text { Bridge at } \\
\mathbf{5 . 1} \mathbf{~ k m}\end{array}$ & $\begin{array}{c}\text { At the } \\
\text { propos- } \\
\text {-ed } \\
\text { Bridge } \\
\text { at 5.1 } \\
\mathbf{k m}\end{array}$ \\
\hline Energy level-m & 1.61 & 1.61 & 1.58 & 1.58 \\
\hline $\begin{array}{l}\text { Water surface } \\
\text { elevation-m }\end{array}$ & 1.59 & 1.59 & 1.58 & 1.57 \\
\hline Flow area-m ${ }^{2}$ & 903.14 & 903.52 & 931.71 & 940.0 \\
\hline Wetted perimeter-m & 276.33 & 276.35 & 280.20 & 289.0 \\
\hline Energy slope & 0.00015 & - & 0.00013 & - \\
\hline Total flow-m ${ }^{3} / \mathrm{s}$ & 822.11 & 822.11 & 785.06 & 788 \\
\hline Top width-m & 240.0 & - & 244.0 & - \\
\hline Velocity & 0.91 & 0.91 & 0.84 & 0.81 \\
\hline $\begin{array}{l}\text { Maximum canal } \\
\text { depth-m }\end{array}$ & 6.25 & 6.25 & 6.26 & 6.26 \\
\hline $\begin{array}{l}\text { Minimum canal } \\
\text { elevation-m }\end{array}$ & -4.69 & - & -4.72 & - \\
\hline Frictional losses-m & 0.01 & 0.00 & 0.01 & 0.00 \\
\hline Sheer force- $\mathrm{N} / \mathrm{m}^{2}$ & 4.93 & 4.93 & 4.20 & 4.51 \\
\hline Total power-N/m/s & 4.49 & 4.48 & 3,54 & 3.85 \\
\hline
\end{tabular}

The Table 2 shows the detailed hydraulic properties under the bridges derived from the model.

The model simulation was then carried out to understand the impact of the new bridge on upstream water levels and flow velocities. For this purpose, a 100 year flood was simulated first without the new bridge and then with the bridge. The span of the bridge varied from $25 \mathrm{~m}$ to 250 $\mathrm{m}$. Table 3 shows the variation of water levels.

From the above results it can be concluded that even if the span of the bridge is reduced to 100 $\mathrm{m}$, the increase in the upstream water levels

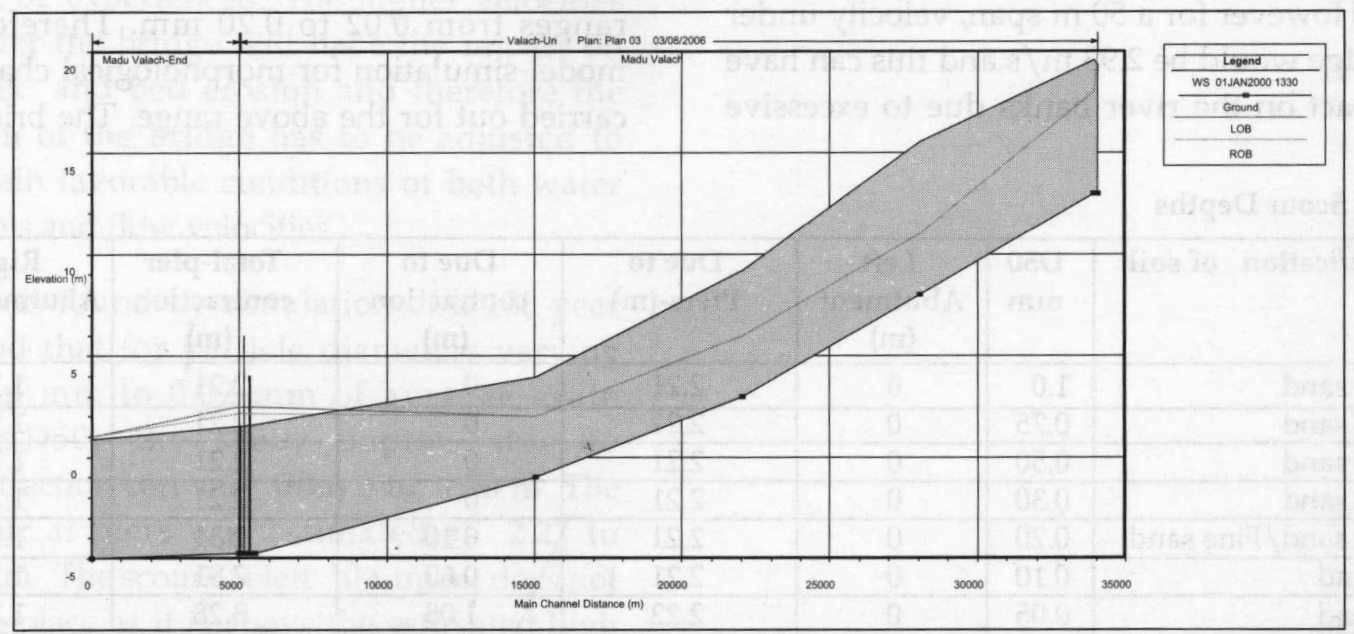

Figure 7 : Hydrodynamic Model Reach-34.0 kms 
Table 3: Variation of upstream water levels in $\mathbf{m}$. Similarly Table 4 shows the variation of flow velocities.

\begin{tabular}{|l|c|c|c|c|c|}
\hline \multicolumn{1}{|c|}{ Location } & $\begin{array}{c}\text { Up } \\
\text { stream } \\
\text { of new } \\
\text { bridgex }\end{array}$ & $\begin{array}{c}\text { At } \mathbf{5 . 1 5} \\
\mathbf{k m}\end{array}$ & $\begin{array}{c}\text { At } \\
\mathbf{5 . 2} \mathbf{~ k m}\end{array}$ & $\begin{array}{c}\text { Up- } \\
\text { stream } \\
\text { of } \\
\text { Existing } \\
\text { bridge }\end{array}$ & $\begin{array}{c}\text { At } \\
\mathbf{5 . 5} \mathbf{~ k m}\end{array}$ \\
\hline Chain age in kms & 5.1 & 5.15 & 5.2 & 5.3 & 5.5 \\
\hline Without the bridge & 1.54 & 1.55 & 1.55 & 1.56 & 1.59 \\
\hline $\begin{array}{l}\text { Bridge with } 250 \mathrm{~m} \\
\text { span }\end{array}$ & 1.57 & 1.57 & 1.58 & 1.59 & 1.60 \\
\hline $\begin{array}{l}\text { Bridge with } 150 \mathrm{~m} \\
\text { span }\end{array}$ & 1.51 & 1.55 & 1.56 & 1.57 & 1.60 \\
\hline $\begin{array}{l}\text { Bridge with } 100 \mathrm{~m} \\
\text { span }\end{array}$ & 1.48 & 1.56 & 1.56 & 1.57 & 1.60 \\
\hline $\begin{array}{l}\text { Bridge with } 50 \mathrm{~m} \\
\text { span }\end{array}$ & 1.27 & 1.58 & 1.58 & 1.59 & 1.63 \\
\hline $\begin{array}{l}\text { Bridge with } 25 \mathrm{~m} \\
\text { span }\end{array}$ & - & 3.71 & 3.72 & 3.725 & 3.73 \\
\hline
\end{tabular}

Table 4: Variation of flow velocities - units $\mathrm{m} / \mathrm{s}$.

\begin{tabular}{|l|l|c|c|c|c|}
\hline \multicolumn{1}{|c|}{ Location } & $\begin{array}{c}\text { Up } \\
\text { stream } \\
\text { of new } \\
\text { bridgex }\end{array}$ & $\begin{array}{c}\text { At } 5.15 \\
\mathbf{k m}\end{array}$ & $\begin{array}{c}\text { At } \\
5.2 \mathrm{~km}\end{array}$ & $\begin{array}{c}\text { Up- } \\
\text { stream } \\
\text { of } \\
\text { Existing } \\
\text { bridge }\end{array}$ & $\begin{array}{c}\text { At } \\
5.5 \mathrm{~km}\end{array}$ \\
\hline Chain age in kms & $\begin{array}{l}5.1 \text { up } \\
\text { stream } \\
\text { of the } \\
\text { bridge }\end{array}$ & 5.15 & 5.2 & $\begin{array}{l}5.3 \text { up- } \\
\text { stream } \\
\text { Existing } \\
\text { bridge }\end{array}$ & 5.5 \\
\hline $\begin{array}{l}\text { Without the bridge } \\
\text { Bridge with } 250 \mathrm{~m} \\
\text { span }\end{array}$ & 0.81 & 0.81 & 0.81 & 0.90 & 0.84 \\
\hline $\begin{array}{l}\text { Bridge with } 150 \mathrm{~m} \\
\text { span }\end{array}$ & 1.23 & 0.81 & 0.81 & 0.91 & 0.84 \\
\hline $\begin{array}{l}\text { Bridge with } 100 \mathrm{~m} \\
\text { span }\end{array}$ & 1.61 & 0.82 & 0.82 & 0.91 & 0.85 \\
\hline $\begin{array}{l}\text { Bridge with } 50 \mathrm{~m} \\
\text { span }\end{array}$ & 2.93 & 0.84 & 0.84 & 0.93 & 0.86 \\
\hline $\begin{array}{l}\text { Bridge with } 25 \mathrm{~m} \\
\text { span }\end{array}$ & - & 0.64 & 0.64 & 0.64 & 0.64 \\
\hline
\end{tabular}

during a 100 year flood is within the permissible limits. However for a $50 \mathrm{~m}$ span, velocity under the bridge would be $2.93 \mathrm{~m} / \mathrm{s}$ and this can have an impact on the river banks due to excessive erosion. The results of $25 \mathrm{~m}$ span bridge showi excessive water levels ranging from $3.71 \mathrm{~m}$ to $3.73 \mathrm{~m}$ between the two bridges and this would cause flooding and therefore it is not acceptable By looking at the hydraulic requirements this analysis shows the adequacy of a $100 \mathrm{~m}$ span bridge satisfying both water levels and velocities in the river estuary.

\section{Coffer damming during construction}

During the construction, coffer damming has to be done for the excavation of foundations and normally river water has to be confined to a smaller width. In order to study the minimum width required to avoid any environmental consequences water levels in the river was simulated for a restricted width. From the results it can be seen that the river can be closed leaving a gap of $50 \mathrm{~m}$ without having any environmental impact during a 10 year flood.

\section{Scour at bridges}

Scours at bridges generally consist of scouring due to flow contraction at the bridge, scour at the piers and abutments. The magnitude of the scour will mainly depend on the flow velocities during major floods and also depends on the type of bed materials available in the river. In addition the shape of piers and abutments are also relevant to scour. Due to prevailing unrest in the area It was not possible to collect river bed samples and therefore scour depths were estimated for assumed particle diameters. According to standard soil classification, the average grain size (D50) of coarse sand ranges between $0.20 \mathrm{~mm}$ to $2.0 \mathrm{~mm}$ and fine sand ranges from 0.02 to $0.20 \mathrm{~mm}$. Therefore the model simulation for morphological changes is carried out for the above range. The bridges in

Table 5: Scour Depths

\begin{tabular}{|l|c|c|c|c|c|c|}
\hline Classification of soil & $\begin{array}{c}\text { D50 } \\
\mathbf{m m}\end{array}$ & $\begin{array}{c}\text { Left } \\
\text { Abutment } \\
\mathbf{( m )}\end{array}$ & $\begin{array}{c}\text { Due to } \\
\text { Piers-(m) }\end{array}$ & $\begin{array}{c}\text { Due to } \\
\text { contraction } \\
\text { (m) }\end{array}$ & $\begin{array}{c}\text { Total-pier } \\
\text { contraction } \\
\text { (m) }\end{array}$ & $\begin{array}{c}\text { Right } \\
\text { Abutment (m) }\end{array}$ \\
\hline Coarse sand & 1.0 & 0 & 2.21 & 0 & 2.21 & 1.18 \\
\hline Coarse sand & 0.75 & 0 & 2.21 & 0 & 2.21 & 1.18 \\
\hline Coarse sand & 0.50 & 0 & 2.21 & 0 & 2.21 & 1.18 \\
\hline Coarse sand & 0.30 & 0 & 2.21 & 0 & 2.21 & 1.18 \\
\hline Coarse sand/Fine sand & 0.20 & 0 & 2.21 & 0.10 & 2.31 & 1.18 \\
\hline Fine sand & 0.10 & 0 & 2.21 & 0.60 & 2.81 & 1.18 \\
\hline Fine sand & 0.05 & 0 & 2.22 & 1.08 & 3.28 & 1.18 \\
\hline Fine sand & 0.02 & 0 & 2.22 & 1.70 & 3.92 & 1.18 \\
\hline
\end{tabular}


the coastal areas are generally found on deep bearing piles and therefore in designing the pile lengths, the estimated scour depth will be taken into consideration.

The results of the scour study for the proposed bridge at $5.1 \mathrm{~km}$ is shown in Table 5 and in Fig. 8 depicts the estimated scour under the bridge.

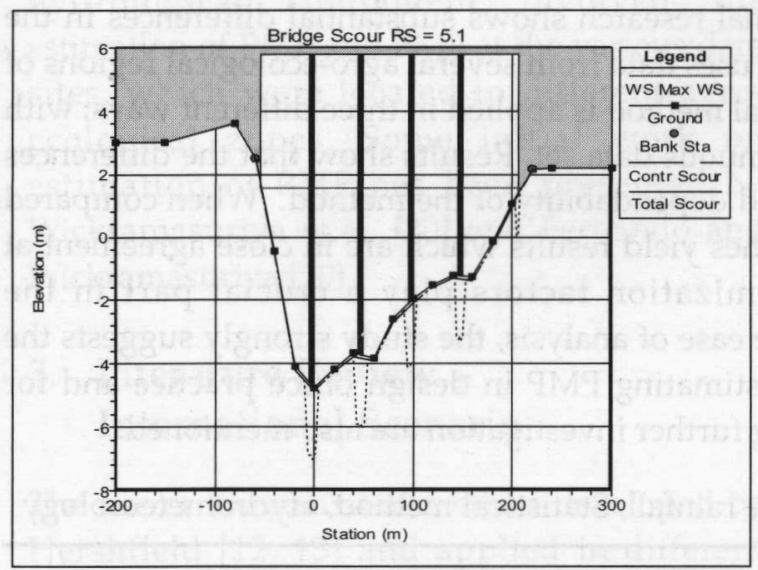

Figure 8: New Bridge- scour depth for D50 $=0.20 \mathrm{~m}$

\section{Conclusions}

1. Simulation of 100 year flood through the Valachchena river estuary shows that $100 \mathrm{~m}$ span would be adequate to meet the hydraulic requirements of the estuary. However the feasibility of filling the approaches to cut down the span of the bridge and social acceptance of the proposal has to be investigated.

2. From the Table 3 it is evident that the reduction of the span does not always contribute for higher water levels. The reduction of the span can increase the flow velocities and therefore lower water levels can be experienced. The higher velocities under the bridge will have the impact on bank and bed erosion and therefore the span of the bridge has to be adjusted to obtain favorable conditions of both water levels and flow velocities.

3. It was found by simulation of a 100 year flood that for particle diameters varying from $\mathrm{mm}$ to $0.02 \mathrm{~mm}$ of average grain size(D50) the scour depth due to contraction can vary from 0 to $1.70 \mathrm{~m}$. The scour at piers was estimated as 2.21 to $3.92 \mathrm{~m}$. The scours at left abutment does not take place as it is above the estimated high flood level.
4. For coffer damming during the construction of foundations, the river width can be narrowed down to $50 \mathrm{~m}$ without any environmental impacts.

\section{Acknowledgement:}

The paper is the out come of investigations carried out by the author as a senior hydrologist of the United Nations Office for Project Services (UNOPS) in Sri Lanka while formulating the parameters of the proposed Oddaimavadi bridge financed by the Government of Spain for the reconstruction of infrastructure facilities damaged by the Tsunami.

The author wishes to thank Mr. Mustafa Iqbal Azam, Chief Technical Advisor and Mr. Rainer Frauenfeld, Country Director of UNOPS for granting permission to publish this paper.

\section{References}

1. PCI Consultants-Design Report of the ADB funded Southern Transport Development Project of the Ministry of Highways

2. US Army Corps of Engineers-HEC-RASModeling Guidelines

3. US Army Corps of Engineers-HEC-HMSModeling Guidelines 